(2) Open Access Full Text Article

LETTER

\title{
Superiority of tiotropium plus olodaterol in comparison with salmeterol plus fluticasone
}

\author{
This article was published in the following Dove Press journal: \\ International Journal of COPD \\ 23 November 2016 \\ Number of times this article has been viewed
}

\section{Tomohiro Tamura \\ Hiroaki Satoh \\ Division of Respiratory Medicine, Mito Medical Center, University of Tsukuba, Ibaraki, Japan}

\section{Dear editor}

We read with interest the article entitled "The lung function profile of once-daily tiotropium and olodaterol via Respimat ${ }^{\circledR}$ is superior to that of twice-daily salmeterol and fluticasone propionate via Accuhaler ${ }^{\circledR}\left(\right.$ ENERGITO $^{\circledR}$ study)" by Beeh et al. ${ }^{1}$ We would appreciate hearing from the authors on the three points as follows. First, the authors described inclusion criteria in the text and showed exclusion criteria in Table S1. However, we could not clearly understand how the authors excluded patients with bronchial asthma. We wondered whether there were a few patients with bronchial asthma included in this study, despite the study showing a superiority of tiotropium plus olodaterol in comparison with salmeterol plus fluticasone. Second, the authors showed that 59 of 288 patients were not randomized due to screening failure. We wondered whether a randomized error in such a large number of patients was unusual in a Phase III study and how the authors evaluated this. Third, as this study was a fourtreatment, complete crossover study, the authors divided patients into four groups. We would appreciate hearing from the authors on what the effect of sequence had on the four treatments. Was there any effect of sequence on the results in this study? Please let us know how we should statistically evaluate its effect on the results.

\section{Disclosure}

The authors report no conflicts of interest in this communication.

\section{Reference}

1. Beeh KM, Derom E, Echave-Sustaeta J, et al. The lung function profile of once-daily tiotropium and olodaterol via Respimat ${ }^{\mathbb{}}$ is superior to that of twice-daily salmeterol and fluticasone propionate via Accuhaler $^{\mathbb{\circledR}}$ (ENERGITO ${ }^{\circledR}$ study). Int J Chron Obstruct Pulmon Dis. 2016;11(1):193-205.
Correspondence: Hiroaki Satoh

Division of Respiratory Medicine, Mito Medical Center, University of Tsukuba, Miya-machi 3-2-7, Mito, Ibaraki 3I0-00I5, Japan

Tel +8| 29 23| 237|

Email hirosato@md.tsukuba.ac.jp 


\section{Author's reply}

Kai-Michael Beeh'

Eric Derom²

José Echave-Sustaeta ${ }^{3}$

Lars Grönke ${ }^{4}$

Alan Hamilton ${ }^{5}$

Dongmei Zhai ${ }^{6}$

Leif Bjermer ${ }^{7}$

'Insaf GmbH Institut für Atemwegsforschung, Wiesbaden, Germany; ${ }^{2}$ Department of Internal Medicine, Ghent University Hospital, Ghent, Belgium; ${ }^{3}$ Servicio de Neumología, Hospital Universitario Quirón, Madrid, Spain; ${ }^{4}$ Boehringer Ingelheim Pharma $\mathrm{GmbH} \&$ Co. KG, Ingelheim, Germany; ${ }^{5}$ Boehringer Ingelheim, Burlington, ON, Canada; ${ }^{\prime}$ InVentiv Health Clinical, Wilmington, DE, USA; ${ }^{7}$ Department of Respiratory Medicine and Allergology, Lund University, Lund, Sweden

Correspondence: Kai-Michael Beeh

Insaf GmbH Institut für Atemwegsforschung,

Biebricher Allee 34, 65I87 Wiesbaden, Germany

$\mathrm{Tel}+496119854410$

Fax +49 6II 9854348

Email k.beeh@insaf-wi.de

\section{Dear editor}

We read with great interest the letter from Tamura and Satoh and would like to provide answers to their queries. The first question related to our method of excluding patients with bronchial asthma. We can clarify that, in addition to the exclusion criteria documented in Table S1, a history of asthma was defined in the protocol as a specific exclusion criterion. Furthermore, for patients with allergic rhinitis, atopy, or a total blood eosinophil count of $\geq 600 / \mathrm{mm}^{3}$, source documentation was required to verify that the patient did not have asthma. Therefore, we consider it unlikely that any patients with bronchial asthma were included in the study.

Regarding the question on the number of patients who failed to be randomized in the study following enrollment, 59 out of 288 patients $(\sim 20 \%)$ were screened but not randomized to treatment in the study. These 59 individuals did not meet the inclusion and/or exclusion criteria and were, therefore, not randomized and did not receive any treatment. This proportion of patients is in line with - and, in fact, smaller than - several large Phase III studies, such as ILLUMINATE, where $37 \%$ of patients screened were not randomized, ${ }^{1}$ SHINE, where $41 \%$ of patients were not randomized to treatment, ${ }^{2}$ and SPARK, where $42 \%$ of patients were screening failures. ${ }^{3}$
The third question related to the method of randomization to treatment groups and whether the sequence of treatments affected the outcome. Patients were randomized to one of four possible treatment sequences via a computer program. The order of the administration of each treatment was not expected to affect the outcome since each treatment was followed by a 21-day washout period and a Williams design was selected, such that each treatment occurred only once within each sequence and once within each period.

\section{Disclosure}

The institution where KMB is employed has received compensation for organizing or participating in advisory boards for Almirall Hermal, Cytos, Chiesi, Boehringer Ingelheim, AstraZeneca, Mundipharma, Novartis, and Revotar Biopharmaceuticals, and for participation in scientific meetings or courses supported by various pharmaceutical companies (Almirall Hermal, AstraZeneca, Boehringer Ingelheim, Novartis, Pfizer, and Takeda) in the past 3 years. KMB's institution has also received consulting fees from Ablynx, Apellis Pharmaceuticals, Chiesi, and Cytos. The institution has received compensation for the design, performance, or participation in single or multicenter clinical trials in the past 3 years from several companies, including Almirall, Boehringer Ingelheim, Cytos, GSK, Mundipharma, Novartis, Pfizer, Revotar Biopharmaceuticals, Sterna AG, and TEVA. ED reports consultancy fees from Actelion, Boehringer, AstraZeneca, and Cipla, advisory board fees for Chiesi, AstraZeneca, and CSL Behring, and speaker fees for GlaxoSmithKline and Boehringer. LG and AH are employees of Boehringer Ingelheim. JES, DZ, and LB report no conflicts of interest in this communication.

\section{References}

1. Vogelmeier CF, Bateman ED, Pallante J, et al. Efficacy and safety of once-daily QVA149 compared with twice-daily salmeterol-fluticasone in patients with chronic obstructive pulmonary disease (ILLUMINATE): a randomised, double-blind, parallel group study. Lancet Respir Med. 2013; 1(1):51-60.

2. Bateman ED, Ferguson GT, Barnes N, et al. Dual bronchodilation with QVA149 versus single bronchodilator therapy: the SHINE study. Eur Respir J. 2013;42(6):1484-1494.

3. Wedzicha JA, Decramer M, Ficker JH, et al. Analysis of chronic obstructive pulmonary disease exacerbations with the dual bronchodilator QVA149 compared with glycopyrronium and tiotropium (SPARK): a randomised, double-blind, parallel-group study. Lancet Respir Med. 2013;1(3):199-209. 
Dove Medical Press encourages responsible, free and frank academic debate. The content of the International Journal of Chronic Obstructive Pulmonary Disease 'letters to the editor' section does not necessarily represent the views of Dove Medical Press, its officers, agents, employees, related entities or the International Journal of Chronic Obstructive Pulmonary Disease editors. While all reasonable steps have been taken to confirm the content of each letter, Dove Medical Press accepts no liability in respect of the content of any letter, nor is it responsible for the content and accuracy of any letter to the editor.

International Journal of COPD

\section{Publish your work in this journal}

The International Journal of COPD is an international, peer-reviewed journal of therapeutics and pharmacology focusing on concise rapid reporting of clinical studies and reviews in COPD. Special focus is given to the pathophysiological processes underlying the disease, intervention programs, patient focused education, and self management protocols.

\section{Dovepress}

This journal is indexed on PubMed Central, MedLine and CAS. The manuscript management system is completely online and includes a very quick and fair peer-review system, which is all easy to use. Visit $\mathrm{http}: / / \mathrm{www}$.dovepress.com/testimonials.php to read real quotes from published authors.

Submit your manuscript here: http://www.dovepress.com/international-journal-of-chronic-obstructive-pulmonary-disease-journal 